\title{
SR, C, O ISOTOPE COMPOSITION IN KIMBERLITES OF THE NORTH-RUSSIAN PROVINCE (USSR).
}

\author{
Kostrovitsky S.I. ${ }^{(1)}$; Skripnichenko V.A. ${ }^{(2)}$; Plusnin G.S. ${ }^{(1)}$ and Bodrov V.A. ${ }^{(3)}$
}

(1) Institute of Geochemistry, Acad. Sci. USSR. 664033, Irkutsk, P.B. 4019, USSR;

(2) Archangelsk Geol. Surv., Archangelsk, USSR; (3) Institute CNIGRI, 113545, Moscow, USSR.

As compared with the Yakutian kimberlites which intruded in the crust of carbonate composition, the kimberlites of the North-Russian Frovince intruded into the Vendian terrigencus sequence mainly consisting of quairtz sandstones, argilitites and siltstones. The sedimentary cover is nearly $1 \mathrm{~km}$ thick:. The new kimberlite provinie is louated in the tectonic mobile zone (within the Zimnegorsto aulacogen) in the marginal part of the platform. This specific gecurrence is respansible for morhological as well as compositional features; (i) existence of sills along with pipes; (ii) a wide compasition variation in kimberlites including appearence of picrites; (iii) development af such secondary minerals as sepiclite and saponite along with serpentine; (iv) low concentration of a carbonate component in the rock of pipes.

The denudation of pipes from the North-Fussian Province is small and amonts to several tens of meters. The upper parts of the pipes are filled up by the rocks of the crater facies (brecias and xenotuff breccias). In the pipe bodies the massive varieties are fairly rarely ubserved. The autoliths in breolias consist of massive fine-porphyritil kimberlites. The sills are also composet of the same type of massive limberlites with a high concentration of carbonate Eomponent.

The isotcope composition of $\mathrm{Sr}$ was determined at the Institute of Geachemistry in Irkutsk, and compositions of $E$ : and $\square$ were measured at CNIGFI Institute in Moscow. The table shows these results as well as calcite gintents in the rocks and $\mathrm{Sr}$ in calcite., It should be noted that $\mathrm{Sr}$ in the carbonate phase was determined from acid extracts. This could lead to overestimating the values of $5 r$ contents in calcite. The isotope Sr composition of silicate phase of kimberlites as well as picrites in pipe bodies has stable values and varies within a narrow range $(\otimes>5 r / \theta 05 r)$ morm $=0.7050-0.7057$. The clase isotopic characteristics indicate a common magmatic scurce for kimberlites and pierites of the North- Russian Frovinie. The carbonate phase of the pipe kimberlites and picrites has

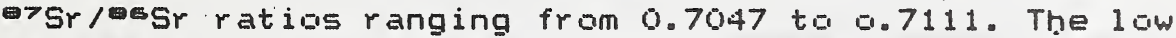
values, similar to those of the silicate phase, are estimated for autoliths. Similar low ratios (0.7036-0.7050) are found for a carbonate component of kimberlite sill Mela that suggets its magmatic nature. The $S r$ isotope composition of hydrothermal calcite (0.7095) is intermediate between the values which characterize the host roicks $(0.711-0.713)$ and the mantle carbonate phase of kimberlite (0.704-0.705).

Together with the study of $\mathrm{Sr}$ isatape camposition $60^{20}$ and $\delta$ c:3 were measured for the same samples in the carbonate component. As compared with the Yakutian kimberlites (for which the correlation between the isotope charalteristics of Sr and 0 has been revealed ( Kostrovitsky, 1986), in kimberlites of the North-Fissian Frovince the correlation between $\mathrm{Sr}$ and $\mathrm{C}$ and betweer $\mathrm{C}$ and $\mathrm{D}$ is more distinctive. 
Table of $\mathrm{Sr}, \mathrm{C}, \mathrm{O}$ isotope composition in kimberlites of the North-Fussian Frovince

\begin{tabular}{|c|c|c|c|c|c|c|c|}
\hline & & & Cac03 & & & & \\
\hline $\mathrm{No}$ & Ficu=r: & $\begin{array}{l}\text { Fipe, } \\
\text { sill }\end{array}$ & $\begin{array}{l}\text { in rack } \\
\text { in wt }\end{array}$ & $\begin{array}{c}\text { Sr, in } \\
\text { wt } \%\end{array}$ & $87 \mathrm{Sr} / 865 r^{-}$ & $\begin{array}{l}\delta=13, \\
\text { in \% }\end{array}$ & $\begin{array}{l}8018, \\
\text { in \%。 }\end{array}$ \\
\hline
\end{tabular}

Kimberlites (carbonate phase)

16 xenotuff- Karpin-

2 - " - koltsov-

$\begin{array}{llllll}\text { Earbonated skaya } & 11.0 & 0.07 & 0.7111 & -1.6 & +22.7\end{array}$

3e breacia Lomonosov 1.51 .01 0 $1092 \quad-5.1+22.1$

$4 c$ autolith Karpin-

\begin{tabular}{|c|c|c|c|c|c|c|}
\hline & skaya & 1.3 & 1.49 & 0.7057 & & \\
\hline " - & Lomongsov & 11.0 & 0.52 & 0.7047 & -6.8 & +12.8 \\
\hline porphyric & Anomaly & & & & & \\
\hline massive & 695 & 45.0 & 0.035 & 0.7079 & -8.1 & +20 \\
\hline $\begin{array}{l}\text { porphyr i= } \\
\text { massive }\end{array}$ & $\begin{array}{l}\text { Mela } \\
\text { silil }\end{array}$ & 80.0 & 0.16 & 0.7036 & -4.7 & +22.1 \\
\hline - " - & " - & 88.0 & 0.22 & 0.7050 & -5.4 & +21.7 \\
\hline
\end{tabular}

Эc hydro-

thermal

veined

calcite Lomonosov $44.0 \quad 0.013 \quad 0.7095 \quad-1.5 \quad+22.6$

Kimberlites (silicate phase)

$\begin{array}{llll}35 & \text { Lomancisov } & 0.015 & 0.7057 \\ 65 & \text { Anomaly-6.95 } & 0.023 & 0.7051 \\ 75 & \text { Mela sil1 } & 0.05 & 0.7052\end{array}$

Picrites (carbinate phase)

10c porphyric Dike

massive Igmo-

$\begin{array}{lllll}\text { Qzersk } & 2.0 & 0.49 & 0.7098 & -1.1\end{array} \quad+26.8$

116 xenctuff Yuras-

$\begin{array}{llllll}\text { breccia skaya } & 13.8 & 0.077 & 0.7085 & -3.9 & +24.3\end{array}$

12 breccia Nenok $1.5 \quad 0.17 \quad 0.7101 \quad 0 \quad-6.6 \quad+21.4$

Picrites (silicate phase)
105
Dike
$13 s$ massive Krutiha
0.023
0.7050
$0.03 \quad 0.7052$

Host rocks (Earbonate phase)

$14 c$ dolomite

(xenolith)

$15 e$ sandstone

$\begin{array}{lllll}80.0 & 0.046 & 0.7108 & -0.6 & +26.4 \\ 14.5 & 0.021 & 0.7131 & -2.8 & +20.2\end{array}$


[:19 value of magmatic cali ite varies from - $4.7 \%$ to $-7.6 \%$, of hydrothermal calcite and carbonized limberlites from

$-1.5 \%$ to $-1.6 \%$, of host robls of the sedimentary Eaver from $-0.6 \%$ to $-2.8 \%$ in the FDE system. Oxygen from the carbonate :omponent of limberlite is marled by a heavy isotope composition, as a rule $S 0^{10}+20 \%$ in the SMow system. The value $\delta 0 x(+12.3 \%$; is similar to the mantle value anly in a single sample of autolith.

Disisusion. The main features of $5 \mathrm{r}, \mathrm{C}$ and 0 isotope systematics in the limberlites from the North-Fussian platform are similar ta those described el sewhere far kimberlites fram the ather provinces. The endogenic melt component in the kimberlites and picrites is charabterized by 1 low $075 r / m 5 r$ (0.704 to 0.706$)$ ratio, typical range of $\delta[: 13$ ( $-5 \%$ to $-8 \%$ ). The relatively high $\delta 019$ values result from profound changes af the l:imberlites by the secandary hydrothermal-metasomatic prouesses. On the whole, the\% ii isotope compositions of $\mathrm{Sr}, \mathrm{L}$ : and $\mathrm{O}$ indicate a significant influence of the host rocks on kimberlites. The carbonate component of kimberlites in the pipe bodies was mainly formed due to this influence. The mantle carbonate is preserved in the inassive porphyritic varieties of limberlites and pierites only.

rostrovitsky S.I. (1986) Geouhemical features of the kimberlite minerals. Fubl. House "Nauta", Novasibirst, 263 P. (in Fussian?. 